\title{
The Effects of Using Color Foods of Children on Immunity Properties and Liver, Kidney on Rats
}

\author{
Sahar S. A. Soltan ${ }^{1,2}$, Manal M. E. M. Shehata ${ }^{1,3}$ \\ ${ }^{1}$ Department of Food Science and Nutrition, Faculty of Food Science and Agriculture, King Feisal University, Hofuf, KSA; ${ }^{2}$ Permanent \\ Address: Department of Nutrition and Food Science, Faculty of Specific Education, El-Fayoum University, El-Fayoum City, Egypt; \\ ${ }^{3}$ Permanent Address: Department of Food Science, Faculty of Agriculture, Zagazig University, Zagazig, Egypt. \\ Email: ssamsoltan@hotmail.com
}

Received April 12 ${ }^{\text {th }}, 2012$; revised May 12 $2^{\text {th }}, 2012$; accepted May 19 , $^{\text {th }} 2012$

\begin{abstract}
Synthetic color is added to foods to replace natural color lost during processing. It causes health problems mainly in children that considered Avery venerable group. This study was carried out investigate the effect of using color foods (Color fruit juice for 6 - $12 \mathrm{hr}$-Tomato ketchup potato chips (TKPC)—color sweet and color chocolate at low (15\%) and high (30\%)) concentration on serum biochemical, WBC (white blood cell) and histopathology of liver and kidney of rats for 13 week. The results indicated that no significant change in body weight gain, serum glucose, HDL and LDL cholesterol compared to control group. TKPC (30\%) showed that significant increase in total cholesterol (TC), triacylglycerol (TG). Low and high concentration of color chocolate and color sweet was exhibited significant increase of TG. The level of ALT and AST was significant increase of rat's administration color fruit juice (for $12 \mathrm{hr}$ ) and TKPC at $30 \%$. High concentration of color foods and long time administration of color fruit juice showed significant increase in serum creatinine and albumin compared to control group. Both low and high consumed of color foods exhibited significant decrease in liver GSH. High concentration of color foods lead to increase number of WBC as the result to the response of the immune system to the inflammation. Color foods were reveled change in histological structure of liver and kidney. In conclusion, the use synthetic color in various foods has adverse effect on some of biochemical analysis; and the liver and kidney histopathological structure.
\end{abstract}

Keywords: Natural Color; Synthetic Color; Food Children; Histopathology of Liver; Antioxidant Enzymes

\section{Introduction}

Color is an important characteristic and selection criterion for choice. The natural and synthetic color additives were used extensively to color foods, drugs and cosmetics [1] because low cost and high tinctorial power [2].

Color additives have long been a part of human cultural. Ancient Egyptian writing mention the use of drug colorants and historians estimate that food colors likely emerged quality of food product. The total world colorant production is estimated to be $8,000,000$ tons per year [3]. The use of food dyes is at least controversial because they are only of essential role. Moreover many of them have been related to health problems mainly in children that are considered a very vulnerable group [4].

Synthetic color in basic food stuffs such as: bread cereals, cheese and milk products, fried fish and meat products, ice cream, juices, sweets, sugar toys, jams and jellies [5,6]. Some of synthetic coloring additives cause severe tension to the consumer as general health for example tartazine $\mathrm{E}_{102}$ and chocolate brown as synthetic coloring agents caused DNA liver and kidney damage as detected by comet assay [7]. Synthetic color for example chocolate color agents decrease rat body weight, serum cholesterol and HDL cholesterol and increase liver enzyme [8,9] Food colorants (amaranth, erythrosine and tartrazine) had a toxic potential to human lymphocytes in vitro and seems that they bind directly to DNA [10]. Tartrazine not only causes changes in hepatic and renal parameter but also their effect become more risk at higher doses because it can induce oxidative stress by formation of free radical.

Very few references concerning the study of the effect of color foods on immunity and histology organs of the body in rat as well as most of the studies were done in determination coloring agent in food and effect different concentration from coloring on biochemical analysis blood. So that the aim of this work was study the effects of using color foods children (juice-sweet-Tomato ketchup potato chips and chocolate color) on immunity properties, serum biochemistry and liver, kidney on rats. 


\section{Materials and Methods}

\subsection{Materials}

Color fruit juice-Tomato ketchup potato chips-color chocolate-color sweet were purchased from local market in El-Ahsa in Saudi Arabia. Potassium hydroxide, potassium phosphate, chloroform, methanol were purchased from Sigma Chemical Co (USA). Kits for blood analysis were purchased from Biodiagnostic Co Egypt. All other reagents used were analytical grade.

\subsection{Methods}

\subsubsection{Animals and Treatments}

A total of 54 young male albino rats weighting about 60 80 gram were used in the present study. They were obtained from College of Veterinary Medicine, King Faisal University. The animal housed individually in stainless steal cages under controlled condition at constant temperature $\left(22^{\circ} \mathrm{C}\right)$ and lighting (12 light-dark cycle) and given free access to food and water at all times. The rats were divided randomly into nine groups, six rats each and were fed on the following diets for 13 weeks:

Group 1: rats were fed basal diet (maintained at control group), standard diet was prepared according to Reeves et al., [11]. It contained 14\% casein, 5\% cellulose, 3.5\% mineral mixture, $1 \%$ vitamin mixture, $0.25 \%$ cholin, 0.3 DL-methionine, 5\% oil and 65\% starch.

Groups 2 and 3: rats were fed on basal diet and drinking color mix fruit juice for 6 and 12 hours.

Groups 4 and 5: rats were fed on basal diet and Low (15\%) and high concentration (30\%) Tomato ketchup potato chips (TKPC).

Groups 6 and 7: rats were fed on basal diet and 15\% and $30 \%$ chocolate color.

Groups 8 and 9: rats were fed on basal diet and 15\% and $30 \%$ sweet color.

Each rat was weighted at the beginning and the end of the experimental. By the end of the experimental period venous blood samples were collected from the orbital sinus of control and food color treated rat's tow fia glass one was containing non agulated material (heparin) for determination hematology and one was used to separation of serum.

\subsubsection{Hematology and Serum Biochemistry}

Hematological examination was performed using a UDIHMI automatic hematology analyzer (France). Aliquots of whole blood sample was mixed with a 4-fold volume of the supplier's buffer containing $0.5 \%$ ethylenetiaminetetra acetic acid (EDTA)-2k and applied to the analyzer for the following parameter: white blood cell (WBC) count and platelet (PLT) count.

\subsubsection{Biochemical Analysis}

Biochemical analysis was done using an Ellipse Auto analyzer, Italy. Total cholesterol (TC), Triglyceride TG, glucose, AST, ALT, creation, albumin were determined by Richomond [12], Jacobs and Vander Mark [13], Trinder [14], Larsen [15], Esen [16], Reitman and Frankel [17]. HDL cholesterol was determined as described by Burstein et al., [18]. LDL cholesterol was calculated according to the equation of Fried Wald et al., [19], Glutathione in liver (GSH) was determination according to Beulter et al., [20].

\subsubsection{Histopatholagical Assessment}

At necropsy, the liver, kidneys were fixed in $10 \%$ buffered formalin until analysis. Tissue slices of all organs/ tissues were routinely processed for paraffin embedding and sections were prepared and stained with hematoxylin and eosin. Histopathological assessment was performed on all tissues of the control group and treatment.

\subsection{Statistical Analysis}

Analysis of the data was of preventative variables in the form of mean \pm SD by SPSS version 17.0 according to Snedecoer and Cochran [21].

\section{Results and Discussion}

In present of this study, it was noticed that, during the administration period (13 weeks) of color foods, rats become more active (hyperactive) and aggressive. Also, rats showed that the skin reddish and irritation after administration of color fruit juice for 6 and 12 hours. These results are in agreement with Juhlin [22], Twaroj [23], Hong et al. [24] food additives are a common cause of chronic urticaria and angioedema in patients. Food additives also caused positive skin and intestinal reaction [25] irritability [26]. Helal et al. [9] proved that food colorants (fast green, annatto and sunset yellow) caused many sings of behavior variation like hyperactivity, nervous motion and become aggressive. Also, after administration of sunset yellow was noticed skin irritation.

Data in Table 1 revealed that administration of color foods did no affect the body weight gain compared to the control group except for group 3. Since the increase and decrease in body weight gain was non significant. This result is in agreement with that of Hashem et al., [4]. Food days (Amaranth, Sunset yellow and Curcumin) did not affect the body weight gain. Meanwhile, administration of color fruit juice for 12 hours showed significant decrease of body weight gain reached to $29.6 \%$. A similar finding was also recorded in rats Brozelleca et al., [27] and Abou El-Zahab et al., [8] and Osman et al., [28] stated that synthetic food colorant cause a significant increase in body weight gain until the fourth month fol- 
lowed by a significant decrease in male and female.

Effect color foods on lipid profile and glucose are shown in Table 2. The data in Table 2 showed that serum total cholesterol level; HDL and LDL were no significant change in all rat's administration color foods except for Group 5. There are significant increases in serum total cholesterol and triacylglycerol levels of rats fed on 30\% potato chips (Group 5). These results may be due to potato absorption levels of lipid during frying potato lead to the cholesterol and triacylglycerol increased. Similar results was obtained by Totoni et al., [29] who reported that significant increase in serum cholesterol and triacylglycerol of rats fed on recovered oil from potato chips after 13 weeks.

Data in Table 2 showed that significant increase in TG in group administration of chocolate and sweet colored at low and high concentrations. Our results are in accordance with the results obtained by Abou El-Zahab et al., [8] and Himiri et al., [30], who observed significant increase in serum triglycerides of rats treated with synthetic color (tartrazine) and chocolate color A and B that containing tartrazine and Carmoisne.

The present study, exhibited no significant change in serum glucose of color foods compared to control group Table 2. Also, administration of color chocolate showed that no significant change in low and high concentration. Our results are in accordance with data reported by Abou El-Zahab et al., [8] who observed no significant increase in serum glucose concentration in rats whose diets were supplemented with chocolate color A and B. Our results are also agreement with Amin et al., [31], who demonstrated that high dose of synthetic color (tartrazine at 500 $\mathrm{mg} / \mathrm{kg}$ b.w) or low dose of Tratrazine (15 mg/kg b.w) caused no significant increase in serum glucose concentration. The present study are in a contrary with Himri et al., [30], who found that a significant increase in serum glucose concentration when administration synthetic color (tartrazine and sulfonic acid) at low and high dose compared to control group.

Effect of administration of color foods on liver function is shown in Table 3. There was no the significant difference in the level of ALT and AST among the different group when compared to control group, except for Group 3 (administration of color fruit juice for 12 hours) and Group 5 (administration of ketchup potato chips) at concentration of $30 \%$. The level of ALT was significant

Table 1. Effect color foods on body weight.

\begin{tabular}{lccc}
\hline \multicolumn{1}{c}{ Groups } & $\mathrm{IBW}^{*}(\mathrm{gm})$ Mean $\pm \mathrm{SD}$ & $\mathrm{FBW}^{\circ}(\mathrm{gm})$ Mean $\pm \mathrm{SD}$ & $\mathrm{BWG}^{\ddagger}(\mathrm{gm}) \mathrm{Mean}^{\mathrm{a}} \pm \mathrm{SD}$ \\
\hline 1) Control & $76.7 \pm 3.2^{\mathrm{ab}}$ & $166.9 \pm 45.1^{\mathrm{bcd}}$ & $90.2 \pm 44.2^{\mathrm{bcd}}$ \\
2) Color fruit juice for 6 hours & $73.04 \pm 3.6^{\mathrm{b}}$ & $143.5 \pm 13.0^{\mathrm{cd}}$ & $61.2 \pm 12.7^{\mathrm{de}}$ \\
3) Color fruit juice for 12 hours & $76.43 \pm 1.2^{\mathrm{ab}}$ & $139.5 \pm 10.9^{\mathrm{c}}$ & $57.4 \pm 10.6^{\mathrm{e}}$ \\
4) Ketchup tomato potato chips 15\% & $76.5 \pm 6.5^{\mathrm{ab}}$ & $177.5 \pm 23.6^{\mathrm{ab}}$ & $101.2 \pm 21.8^{\mathrm{b}}$ \\
5) Ketchup tomato potato chips 30\% & $73.8 \pm 6.4^{\mathrm{b}}$ & $175.1 \pm 19.3^{\mathrm{abc}}$ & $101.3 \pm 14.2^{\mathrm{b}}$ \\
6) Chocolate color 15\% & $73.2 \pm 7.1^{\mathrm{b}}$ & $180.9 \pm 23.4^{\mathrm{ab}}$ & $107.2 \pm 26.7^{\mathrm{b}}$ \\
7) Chocolate color 30\% & $76.04 \pm 4.8^{\mathrm{ab}}$ & $169.4 \pm 20.2^{\mathrm{bcd}}$ & $93.4 \pm 20.3^{\mathrm{bc}}$ \\
8) Sweet color 15\% & $78.4 \pm 4.7^{\mathrm{ab}}$ & $164.1 \pm 20.0^{\mathrm{bcd}}$ & $85.7 \pm 21.6^{\mathrm{bcde}}$ \\
9) Sweet color 30\% & $73.5 \pm 4.7^{\mathrm{b}}$ & $139.8 \pm 12.8^{\mathrm{c}}$ & $66.3 \pm 15.6^{\text {cde }}$ \\
\hline
\end{tabular}

*Initial body weight; ${ }^{\circ}$ Final body weight; ${ }^{\dagger}$ Body weight gain.

Table 2. Effect color foods on lipid profile and glucose.

\begin{tabular}{|c|c|c|c|c|c|}
\hline Grope & $\begin{array}{c}\text { Total Cholesterol } \\
\text { mg/dl }\end{array}$ & $\begin{array}{c}\text { Total Triacylglycerol } \\
\text { mg/dl }\end{array}$ & $\begin{array}{c}\text { HDL Cholesterol } \\
\text { mg/dl }\end{array}$ & $\begin{array}{l}\text { LDL Cholesterol } \\
\text { mg/dl }\end{array}$ & Glucose mg/dl \\
\hline 1) Control & $96.95 \pm 15.2^{\mathrm{bc}}$ & $49.58 \pm 5.7^{c}$ & $62.68 \pm 10.8^{\mathrm{ab}}$ & $24.30 \pm 14.5^{\mathrm{bc}}$ & $104.75 \pm 0.64^{\mathrm{ab}}$ \\
\hline 2) Color fruit juice for 6 hours & $95.05 \pm 6.2^{\mathrm{a}}$ & $38.40 \pm 3.7^{d}$ & $60.88 \pm 7.9^{\mathrm{ab}}$ & $26.48 \pm 9.5^{\mathrm{bc}}$ & $101.78 \pm 0.16^{\mathrm{ab}}$ \\
\hline 3) Color fruit juice for 12 hours & $98.82 \pm 4.9^{\mathrm{bc}}$ & $38.88 \pm 11.7^{\mathrm{d}}$ & $57.98 \pm 8.2^{b}$ & $33.05 \pm 8.4^{\mathrm{bc}}$ & $97.42 \pm 0.30^{\mathrm{ab}}$ \\
\hline 4) Ketchup tomato potato chips $15 \%$ & $100.18 \pm 6.6^{\mathrm{bc}}$ & $55.37 \pm 2.3^{c}$ & $60.77 \pm 7.8^{\mathrm{ab}}$ & $30.03 \pm 4.6^{\mathrm{bc}}$ & $112.10 \pm 0.50^{\mathrm{a}}$ \\
\hline 5) Ketchup tomato potato chips 30\% & $127.13 \pm 41.7^{\mathrm{a}}$ & $64.50 \pm 4.3^{\mathrm{ab}}$ & $57.02 \pm 6.8^{\mathrm{b}}$ & $57.18 \pm 46.6^{\mathrm{a}}$ & $97.92 \pm 2.7^{\mathrm{ab}}$ \\
\hline 6) Chocolate color $15 \%$ & $97.63 \pm 3.7^{\mathrm{bc}}$ & $65.15 \pm 8.7^{\mathrm{ab}}$ & $67.70 \pm 2.1^{\mathrm{a}}$ & $16.90 \pm 4.8^{\mathrm{c}}$ & $81.60 \pm 6.9^{b}$ \\
\hline 7) Chocolate color $30 \%$ & $104.48 \pm 13.6^{\mathrm{bc}}$ & $67.97 \pm 7.5^{\mathrm{a}}$ & $62.00 \pm 4.9^{\mathrm{ab}}$ & $28.89 \pm 14.7^{\mathrm{bc}}$ & $101.55 \pm 0.39^{\mathrm{ab}}$ \\
\hline 8) Sweet color $15 \%$ & $110.77 \pm 14.9^{\mathrm{abc}}$ & $69.77 \pm 7.3^{\mathrm{a}}$ & $61.10 \pm 9.4^{\mathrm{ab}}$ & $35.71 \pm 9.1^{\mathrm{bc}}$ & $83.65 \pm 0.29^{b}$ \\
\hline 9) Sweet color $30 \%$ & $117.17 \pm 13.7^{\mathrm{ab}}$ & $70.85 \pm 8.6^{\mathrm{a}}$ & $56.08 \pm 5.5^{b}$ & $46.75 \pm 14.3^{\mathrm{ab}}$ & $103.90 \pm 3.3^{\mathrm{ab}}$ \\
\hline
\end{tabular}


Table 3. Effect color foods on function of liver and kidney.

\begin{tabular}{|c|c|c|c|c|}
\hline Grope & $\begin{array}{l}\text { ALT }(\mu \mathrm{l} / \mathrm{dl}) \\
\text { Mean } \pm \text { SD }\end{array}$ & $\begin{array}{l}\text { AST }(\mu \mathrm{l} / \mathrm{dl}) \\
\text { Mean } \pm \text { SD }\end{array}$ & $\begin{array}{l}\text { Creatinine }(\mathrm{mg} / \mathrm{dl}) \\
\quad \text { Mean } \pm \mathrm{SD}\end{array}$ & $\begin{array}{l}\text { Albumin }(\mathrm{mg} / \mathrm{dl}) \\
\text { Mean } \pm \text { SD }\end{array}$ \\
\hline 1) Control & $43.48 \pm 18.5^{b}$ & $95.90 \pm 4.6^{\mathrm{b}}$ & $14.35 \pm 3.8^{\mathrm{b}}$ & $3.27 \pm 0.84^{\mathrm{b}}$ \\
\hline 2) Color fruit juice for 6 hours & $51.23 \pm 1.4^{\mathrm{ab}}$ & $97.7 \pm 4.8^{\mathrm{b}}$ & $16.83 \pm 4.8^{\mathrm{ab}}$ & $3.73 \pm 5.8^{\mathrm{ab}}$ \\
\hline 3) Color fruit juice for 12 hours & $61.7 \pm 6.4^{\mathrm{a}}$ & $100.43 \pm 0.67^{\mathrm{b}}$ & $19.33 \pm 3.2^{\mathrm{a}}$ & $4.20 \pm 0.32^{\mathrm{a}}$ \\
\hline 4) Ketchup tomato potato chips $15 \%$ & $47.13 \pm 12.3^{b}$ & $99.60 \pm 3.7^{\mathrm{b}}$ & $16.53 \pm 2.3^{\mathrm{ab}}$ & $3.67 \pm 0.40^{\mathrm{ab}}$ \\
\hline 5) Ketchup tomato potato chips $30 \%$ & $55.03 \pm 4.4^{\mathrm{ab}}$ & $106.63 \pm 9.7^{\mathrm{a}}$ & $18.17 \pm 3.7^{\mathrm{ab}}$ & $4.27 \pm 0.65^{\mathrm{a}}$ \\
\hline 6) Chocolate color $15 \%$ & $47.10 \pm 18.2^{\mathrm{b}}$ & $95.20 \pm 2.4^{\mathrm{b}}$ & $14.77 \pm 3.0^{\mathrm{b}}$ & $3.40 \pm 0.79^{\mathrm{ab}}$ \\
\hline 7) Chocolate color $30 \%$ & $56.60 \pm 7.8^{\mathrm{ab}}$ & $96.10 \pm 3.7^{b}$ & $16.30 \pm 3.1^{\mathrm{ab}}$ & $3.4 \pm 1.1^{\mathrm{a}}$ \\
\hline 8) Sweet color $15 \%$ & $48.20 \pm 6.4^{\mathrm{b}}$ & $95.90 \pm 3.1^{\mathrm{b}}$ & $15.05 \pm 3.5^{\mathrm{ab}}$ & $3.9 \pm 0.51^{\mathrm{ab}}$ \\
\hline 9) Sweet color $30 \%$ & $54.30 \pm 4.5^{\mathrm{ab}}$ & $97.10 \pm 3.7^{\mathrm{b}}$ & $16.77 \pm 2.8^{\mathrm{ab}}$ & $3.53 \pm 0.68^{\mathrm{ab}}$ \\
\hline
\end{tabular}

increase of group administration of color fruit juice for 12 hours reached to $26.6 \%$, while the same concentration show no significant increase in serum AST when compared control group. Also, the level of AST was significant increase in group administration of ketchup potato chips at concentration $30 \%$ reached to $11.2 \%$. A significant increase in serum ALT and AST may be attributed those change in liver function to be heptocellular impairment level of intracellular enzymes into the blood [32]. The release of a normally high level of specific tissue enzymes into blood stream is dependent on both the degree and type of damage exerted by the toxic compound administration $[33,34]$.

Color fruit juice containing sunset yellow, tartazine and carmosine lead to significant increase in ALT of serum rats. These results are accordance with data reported by Mekkawy et al., [35] and Amin et al., [31], who indicated that rats which consumed high dose synthetic color (Tartarzine, Carmoisin, sunset yellow and fast green) showed a significant increase in serum ALT and AST when compared to control rats.

A significant increase in serum AST of rats fed on high concentration ketchup potato chips may be due to formed acrylamide during fried to potato chips. Tareke et al., [36] reported that among fried and backed starch food contain acrylsmide (AA) at part per million level has challenged investigators worldwide to define more completely the toxic mechanisms and internal exposures from experimental animal models and humans in order to develop a relevant risk assessment. These results are approved by Awad et al., [37], who reported that there was a significant increase in AST was observed after treatment with $1 \mathrm{mM}$ AA. AST is an index for mitochondria damage Koplorich [38].

Data in Table 3, showed that effect administration of color foods on kidney function. The rats consumed high concentration of color food (30\%) and long time administration of color fruit juice (12 hr) showed significant increase in serum creatinine and albumin concentration as compared to the control group. We believed that the significant elevation in creatinine level is closely related to the impairment of renal function. These results are in agreement with Helal et al., [9] and Amin et al., [31] who decided that the a significant elevation in serum creatinine and urea in rats consumed a synthetic or natural food color after 30 days of treatment. Furthermore, the present findings are in accordance with data reported by Ashour and Adelaziz [39], who observed a significant elevation in serum creatinine and urea level of rats doses with Azo dye (fast green) orally for 35 days. Our results disagreement with Hashem et al., [4], showed that oral administration of Amaranth at a dose $47 \mathrm{mg} / \mathrm{kg}$ b.w and sunset yellow in dose $313 \mathrm{mg} / \mathrm{kg}$ b.w did not affect total serum protein and albumin compared to control group.

The effect of color foods on activity antioxidant enzyme (GSH) in rat's hepatocytes and platelets and white blood cell WBC is illustrated in Table 4. Both low and high consumed of color food exhibited a significant decrease in liver GSH content when compared to control group. These results may be due to the synthetic color caused oxidation of fatty acids in biological membranes lead to increase free radicals is able to caused auto-oxidation of the hepatic cells. So that GSH consumed to prevent the cell death by toxic radicals, so their level in liver homogenate was decrease especially at high concentration. Our results approved Amin et al., [31], who reported that rats consumed low and high doses of synthetic color (tartarzine and carmoisine) induced a significant decrease in GSH and catalase activity.

Administration of color foods did not affect of platelets as compared to control. Rats fed on ketchup potato chips, chocolate colored, sweet color at $30 \%$ and color fruit juice for $12 \mathrm{hr}$ revealed significant increase in the number of WBC as compared to the control group. Increase the count of WBC may be due to acute inflammation [27]. The immune system has response of inflammation and lead to increase WBC. These results are disagreement with Hashem et al., [4] who reported that syn- 
Table 4. Effect color foods on antioxidant enzyme and immunity.

\begin{tabular}{lccc}
\hline \multicolumn{1}{c}{ Groups } & WBC $\left(\times 10^{2} / \mu \mathrm{L}\right)$ Mean $\pm \mathrm{SD}$ & Platelets $\left(\times 10^{4} / \mu \mathrm{L}\right)$ Mean $\pm \mathrm{SD}$ & Glutathione mM/L \\
\hline 1) Control & $7.87 \pm 2.18^{\mathrm{b}}$ & $1077.83 \pm 150.6^{\mathrm{c}}$ & $6.48 \pm 10.5^{\mathrm{a}}$ \\
2) Color fruit juice for 6 hours & $7.72 \pm 1.77^{\mathrm{b}}$ & $1133.00 \pm 151.0^{\mathrm{abc}}$ & $5.93 \pm 4.5^{\mathrm{bc}}$ \\
3) Color fruit juice for 12 hours & $7.77 \pm 1.53^{\mathrm{b}}$ & $1150.00 \pm 138.1^{\mathrm{abc}}$ & $5.68 \pm 19.3^{\mathrm{b}}$ \\
4) Ketchup tomato potato chips 15\% & $7.80 \pm 1.18^{\mathrm{b}}$ & $1084.17 \pm 170.1^{\mathrm{bc}}$ & $5.96 \pm 9.2^{\mathrm{bc}}$ \\
5) Ketchup tomato potato chips 30\% & $10.07 \pm 1.19^{\mathrm{a}}$ & $1165.50 \pm 107.1^{\mathrm{abc}}$ & $5.99 \pm 44.3^{\mathrm{bc}}$ \\
6) Chocolate color 15\% & $10.05 \pm 1.51^{\mathrm{a}}$ & $1078.33 \pm 102.2^{\mathrm{c}}$ & $6.04 \pm 35.8^{\mathrm{bc}}$ \\
7) Chocolate color 30\% & $10.80 \pm 1.76^{\mathrm{a}}$ & $1173.50 \pm 92.9^{\mathrm{abc}}$ & $5.69 \pm 9.9^{\mathrm{bc}}$ \\
8) Sweet color 15\% & $9.43 \pm 1.24^{\mathrm{ab}}$ & $1071.33 \pm 60.2^{\mathrm{c}}$ & $6.19 \pm 13.4^{\mathrm{ab}}$ \\
9) Sweet color 30\% & $10.88 \pm 1.26^{\mathrm{a}}$ & $1185.67 \pm 79.6^{\mathrm{abc}}$ & $5.96 \pm 6.9^{\mathrm{bc}}$ \\
\hline
\end{tabular}

thetic color (sunset yellow, amaranth) exerted a depressing effect on the cellular but not humeral immune response.

\subsection{Histopatholagical Assessment}

\subsubsection{Liver}

Liver of control rat (Group 1) showed that the normal histological structure of hepatic. Also microscopic, liver of Group 2 drinking fruit juice color for 6 hours showed no histopathological changes. Meanwhile, liver of Group 3 drinking fruit juice color for 12 hour revealed hydropic degeneration of hepatocytes Figure 1. Examined sections from Group 4 fed on potato chips 15\% showed hydropic degeneration of hepatocytes, sinusoidal leucocytes and congestion of hepatic sinusoids, hydropic degeneration of hepatocytes (Figure 2), dilatation and congestion of hepatic sinusoids as well as sinusoidal leucocytes (Figure 3). Moreover liver of Group 5 fed on 30\% potato chips revealed cytoplasmic vacuolization of hepatocytes and portal infiltration with leucocytes (Figure 4). This results may be due to presence acrylamide is formed during fried potato chips at high temperature. Acrylamide showed cell damage of hepatocytes in rats [36], because increasing in the cell membrane permeability [40]. These results are agreement with El-Sayyad et al., [41] who reported that acrylamid revealed histological abnormalities characterized of liver

Meanwhile, liver of Group 6 fed on 15\% chocolate revealed no histopathological change. Liver of Group 7 fed on $30 \%$ chocolate showed congestion of central vein and kupffer cells activation (Figure 5). Liver rats of Group 8 fed on $15 \%$ sweet color showed no histological changes. Meanwhile group 9 fed on 30\% sweet color revealed slight hydropic degeneration of hepatpcytes. These results are agreement with the Sharma et al. [42], reported that synthetic color has adverse effect on vital organs. At low dose synthetic color, the liver revealed a disruption of hepatic cells near the central vein, and hepatocellular damaged.

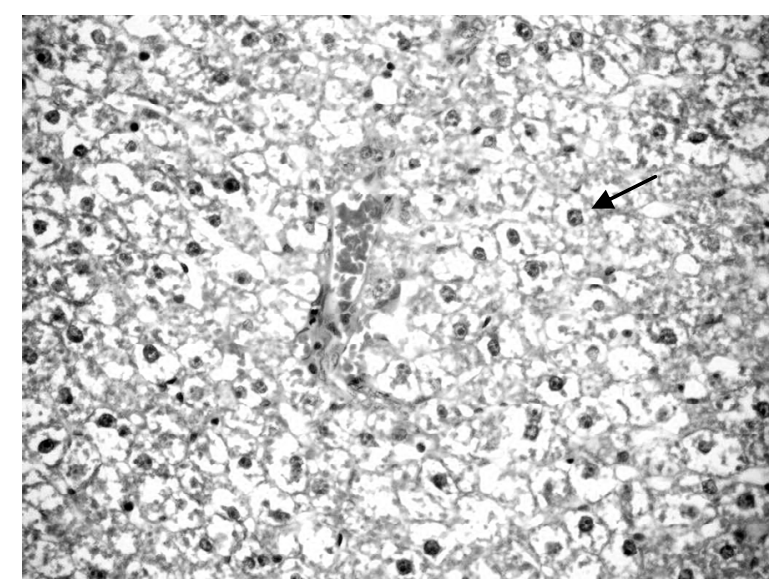

Figure 1. Liver of rats drinking color fruit juice for 12 hours.

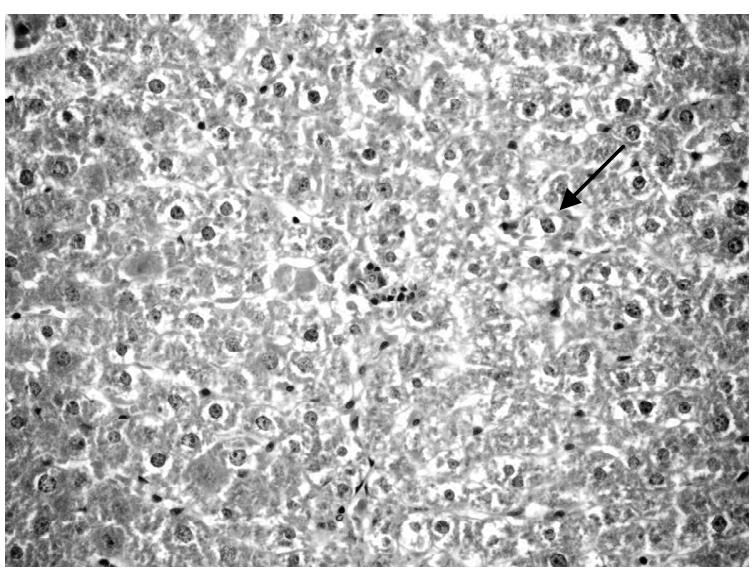

Figure 2. Liver rats fed on $15 \%$ potato chips.

\subsubsection{Kidney}

Microscopically, kidneys of rats of group 1 showed normal histological structure meanwhile group 2 revealed congestion of renal blood vessels and presence of protein cast in the lumen of some renal tubules. Moreover kidneys rats of group 3 showed congestion of intertubular blood vessels, congestion of glomerular tuft as well as presence of protein cast in the lumen of renal tubules 


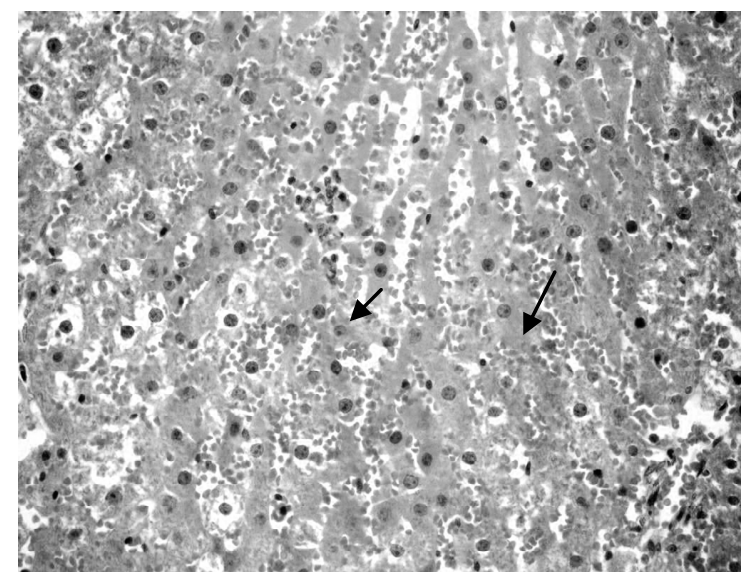

Figure 3. Liver fed on $15 \%$ potato chips.

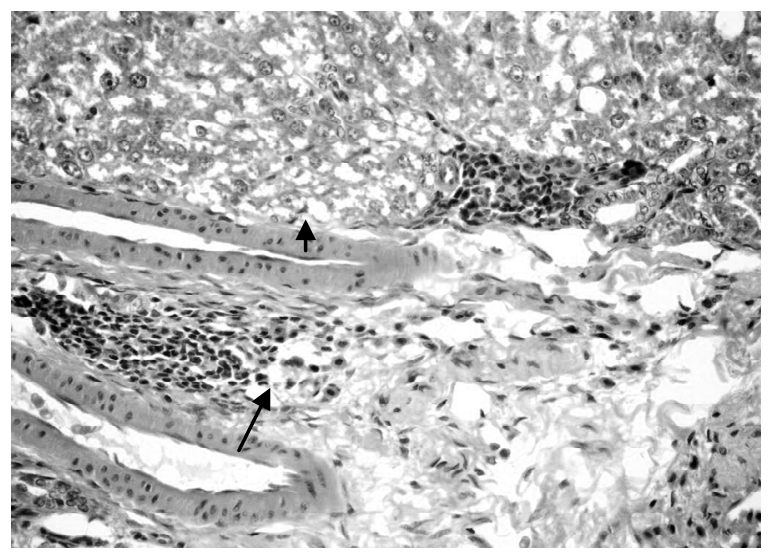

Figure 4. Liver rats fed on $30 \%$ potato chips.

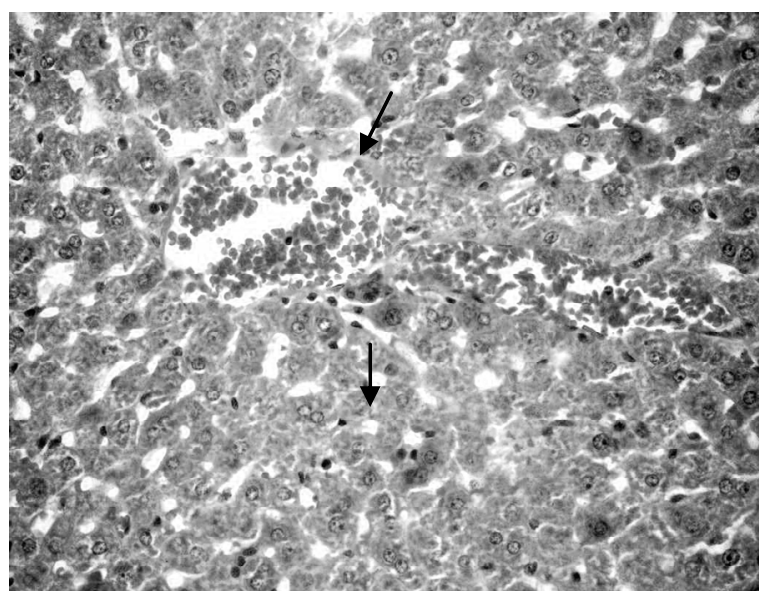

Figure 5. Liver rats fed $30 \%$ chocolate.

(Figure 6). Some examined section of group 4 revealed perivascular leucocyteic cells infiltration (mainly eosinophiles) Figure 7 when other section from this group showed apparent normal renal parenchyma. Mean while, kidneys of rats of group 5 showed eosinophilic protein cast in the lumen of renal tubules (Figure 8). Kidney rats of group 6 revealed no histopathological change. Exam- ined sections of group 7 revealed eosinophilic protein cast in the lumen of some renal tubules, and congestion of intertubular blood vessels (Figure 9). Kidneys of group 8 fed on 15\% sweet color revealed slight congestion of glanerular tufts was the only change observed in kidney. However, some section from group revealed presence of protein cast in the lumen of some renal tubules, moreover Kidney rats of Group 9 fed on 30\% sweet color revealed necrobiotic changes of epithelial

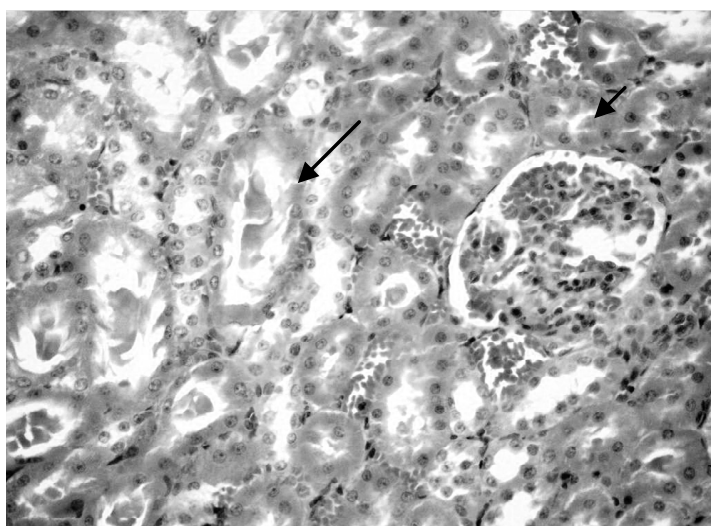

Figure 6. Kidney of rats dirking fruit juice color for 12 hours.

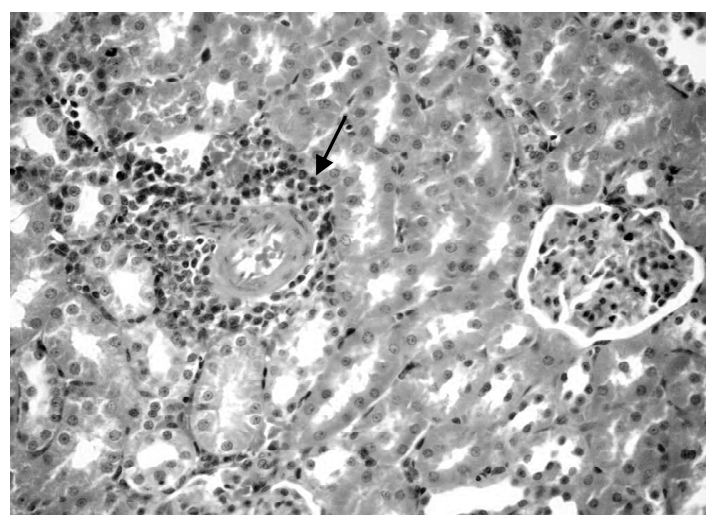

Figure 7. Kidney of rats fed on $15 \%$ potato chips.

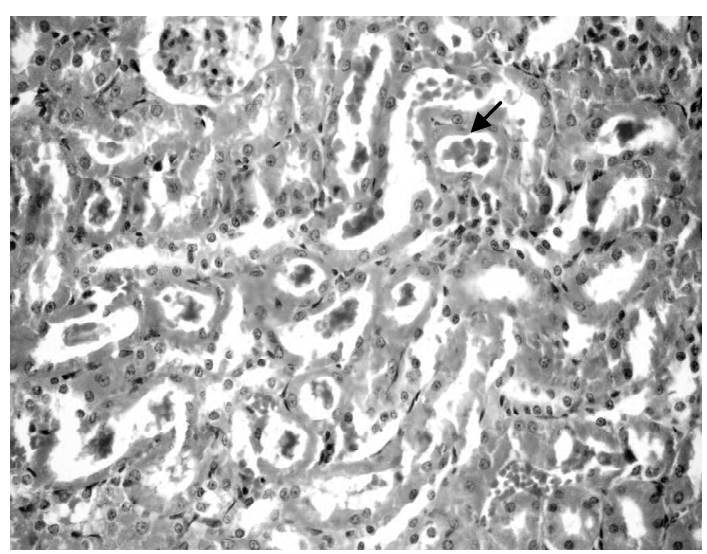

Figure 8. Kidney of rats fed on $30 \%$ potato chips. 


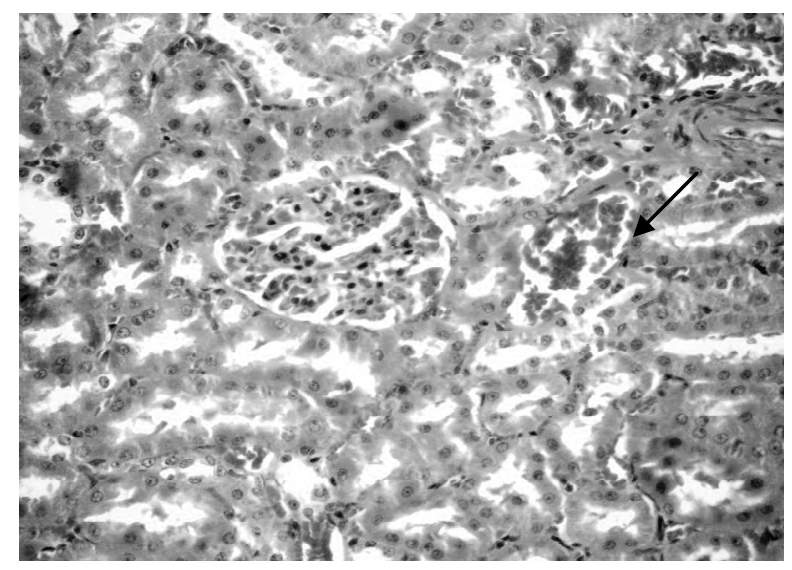

Figure 9. Kidney of rats fed on $30 \%$ chocolate.

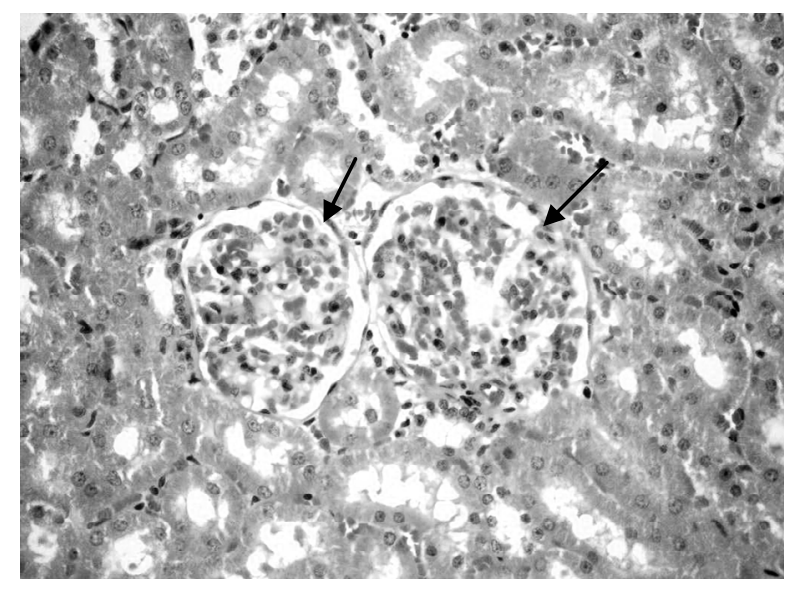

Figure 10. Kidney of rats fed on $30 \%$ sweet color.

liming renal tubules and congestion of glanerular tufts (Figure 10). The presence synthetic color in food cusses injured of kidney [42].

\section{Conclusion}

The use synthetic color in various foods has adverse effect on some of biochemical analysis specifically at high concentration and administration for along time. However, its lead to the change in liver and kidney histopathological structure and increase in WBC which indicated that induce inflammation specific ketchup potato chips. Meanwhile, showed that hyperactive and skin reddish and irritation (sensitive). So, we recommended low administration of color foods of children specific Ketchup potato chips.

\section{Acknowledgements}

The authors would like to thank the Deanship of Scientific Research at King Faisal University in Kingdom of Saudi Arabia for funding for this research and the efforts made in completed.

\section{REFERENCES}

[1] J. B. Hallagan, D. C. Allen and J. F. Barzelleca, “The Safety and Regulatory Status of Food, Drug and Cosmetic Color Additives Exempt from Certification,” Food Chemical and Toxicology, Vol. 33, No. 6, 1995, pp. 515-528. doi:10.1016/0278-6915(95)00010-Y

[2] S. Babu and I. S. Shenoliker, "Health and Nutritional Implications of Food Colors," Indian Journal of Medical Research, Vol. 102, No. 3, 1995, pp. 245-255.

[3] S. M. Revanker and S. S. Lele, "Synthetic Dyes Decolorization by White Rot Fungus, Ganoderma SP. WR-1,” Bioresearches Technology, Vol. 98, 2007, pp. 775-780.

[4] M. M. Hashem, A. H. Atta, M. S. Arbid, S. A. Nada and G. F. Asaad, "Immunological Studies on Amaranth Sunset Yellow and Curcumin as Food Coloring Agents in Albino Rats," Food and Chemical Toxicology, Vol. 48, No. 6, 2010, pp. 1581-1586. doi:10.1016/j.fct.2010.03.028

[5] C. Madsen, "Chemicals in Food and Allergy: Food Fiction,” Environmental Toxicology and Pharmacology, Vol. 4, No. 1-2, 1997, pp. 115-120. doi:10.1016/S1382-6689(97)10051-5

[6] M. Tripathi, S. K. Khanna and M. Das, "Surveillance on Use of Synthetic Colors in Eatables Vis Prevention of Food Adulteration Act of India,” Food Control, Vol. 18, No. 3, 2007, pp. 211-219. doi:10.1016/j.foodcont.2005.09.016

[7] G. M. Hassan, "Effect of Some Synthetic Coloring Additives on DNA Damage and Chromosomal Aberration of Rats,” Arab Journal. Biotechnology, Vol. 13, No. 1, 2009, pp. 13-24.

[8] H. Abou-El-Zahab and Z. G. El-Khyat, "Physiological Effect of Some Synthetic Food Coloring Additives Rats,” Pro-Boll Chemical Farm, Vol. 136, No. 10, 1979, pp. 615627.

[9] G. E. Helal, A. M. Zaahkouk and A. H. Mekkaway, "Effect of Some Food Colorants (Synthetic and Natural Products) of Young Albino Rats," Egyptian Journal of Hospital Medicine, Vol. 1, No. 2, 2000, pp. 103-113.

[10] P. Mpountouka, A. Panatzaki, E. Kostareli, P. Christodoulou, D. Kareli, S. Poliliou, C. Mourelatos, V. Lambropoulou and T. A. Lialiaris, "Cytogenetic Evaluation and DNA Interaction Studies of the Food Colorants Amaranth, Erythrosine and Tartrazine," Food and Chemical Toxicology, Vol. 48, No. 10, 2010, pp. 2934-2944. doi:10.1016/j.fct.2010.07.030

[11] R. G. Reeves, F. H. Nielsen and G. C. Fahey, "AIN-93 Purified Diets for Laboratory Rodents,” Journal of Nutrition, Vol. 123, No. 1, 1993, p. 1939.

[12] N. Richmond, "Determination or Serum Total Cholesterol,” Clinical Chemistry, Vol. 19, 1973, p. 1350.

[13] N. J. Jacobs and P. J. V. Mark, "Determination of Serum Triacylglycerol. Arch,” Biochemical Biophysics, Vol. 88, No. 2, 1960, p. 250. doi:10.1016/0003-9861(60)90230-7

[14] P. Trinder, “Determination of Glucose in Blood,” Annals of Clinical Biochemistry, Vol. 6, No. 2, 1963, p. 24.

[15] K. Larsen, “Creatinine Assay Be a Reaction Principle,” 
Clinica Chimica Acta, Vol. 41, 1972, p. 209. doi:10.1016/0009-8981(72)90513-X

[16] A. Esen, "A Simple Method for Quantitive, Semi Quantitive and Qualitative Assay of Protein," Analytical Biochemistry, Vol. 80, 1987, pp. 264-273.

[17] S. Reitman and S. Frankel, "A Calorimetric Method for Determination of Serum AST," American Journal Clinical Pathology, Vol. 18, 1957, p. 26.

[18] M. Burstein, H. R. Scholnick and R. Haarfin, "Rapid Method for Isolation of Lipoprotein from Human Serum by Precipitation with Polyamine," Lipid Research, Vol. 11, 1970, pp. 385-395.

[19] W. T. F. Wald, K. T. Levy and D. S. Fredrickson, "Estimation of the Concentration of HDL Cholesterol in Plasma without Use of the Preparative Ultra Centrifuge,” Clinical Chemistry, Vol. 18, No. 6, 1972, pp. 499-504.

[20] E. Beulter, O. Duron and M. B. Kelly, "Determination of Glutathione,” Journal of Laboratory and Clinical Medicine, Vol. 61, 1963, p. 882.

[21] G. W. Snedecore and W. G. Cochran, "Statistical Methods,” 6th Edition, Lowa State University Press, Amers, 1967.

[22] L. Juhlin, "Recurrent Urticaria: Clinical Investigation of 330 Patients," The British Journal of Dermatology, Vol. 104, No. 4, pp. 369-381. doi:10.1111/j.1365-2133.1981.tb15306.x

[23] F. J. Twaroj, "Urticaria in Childhood: Pathogens and Management," Pediatric Clinics of North America, Vol. 30, 1983, pp. 887-898.

[24] S. P. Hong, H. S. Park, M. K. Lee and C. S. Hong, “Oral Provocation Tests with Aspirin and Food Additives in Asthmatic Patient," Yonset Medical Journal, Vol. 30, No. 4, 1989, pp. 339-345.

[25] H. P. Van-Bever, M. Doxy and W. J. Steven, "Food and Food Additives in Severe a Topic Dermatitis," Allergy (Copenhagen), Vol. 44, No. 1, 1989, pp. 588-594.

[26] S. K. Rowe, "Synthetic Food Colorings and Hyperactivity: A Double-Blind Crossover Study,” Australian Paediatric Journal, Vol. 24, No. 2, 1988, pp. 143-147.

[27] J. F. Brozelleca, J. W. Olson and F. E. Reno, "Life Time Toxicity Carcinogenicity Study of FD \& Red n.40 (Allura Red) in Sprague-Dawley Rats,” Food Chemical and Toxicology, Vol. 27, No. 11, 1989, pp. 701-706.

[28] M. A. Osman, A. Afifi, R. M. Hussein, B. Kamilia, A. A. Aziz and S. H. Salah, "Long-Term Biochemical and Genotoxicity Studies of Four Synthetic Food and Drug Colorants in Mice,” Bulletin of Faculty of Pharmacy, Vol. 33, No. 1, 1995, pp. 13-21.

[29] N. Totani, M. Yawatam. Y. Ojiri and Y. Fuji Okay, "Effect of Trace Acrylamide Intake in Wister Rats,” Journal of Oles Science, Vol. 56, No. 9, 2009, pp. 501-506. doi:10.5650/jos.56.501

[30] I. Himiri, S. Bellahcen, F. Souna, F. Belmekki, M. Aziz, M. Bnouham, Z. Berkia, H. Mekhfi and E. Saaluri, "A 90-Day Oral Toxicity Study of Tartrazine, a Synthetic
Food Dye, in Wister Rats,” International Journal of Pharmacy and Pharmaceutical Sciences, Vol. 3, No. 2, 2011, pp. 159-169.

[31] K. A. Amin, H. A. Hameid and A. H. Abd Elsttar, "Effect of Food Azo Dyes Tartrazine and Carmoisine on Biochemical Parameters Related to Renal, Hepatic Function and Oxidative Stress Biomarkers in Young Mal Rats," Food and Chemical Toxicology, Vol. 48, No. 10, 2010, pp. 2994-2999. doi:10.1016/j.fct.2010.07.039

[32] E. A. Abdel-Rahim, E. A. Ahmed, G. E. El-Desoky and M. E. Ramadan, "Biochemical Role of Some Natural and Synthetic Colorants on Liver Function of Rats,” Mania Journal of Agriculture Research, Vol. 9, No. 3, 1987, pp. 11-17.

[33] J. K. Malki, R. V. Singh, R. C. Gupta, P. N. Varman and B. S. Paul's, "Influence of Fenitrothion on in Vitro Incorporation of Acetate 14-in Liver Lipid and on Various Tissue Enzymes in Rats," Journal of Nuclear Agriculture \& Biology, Vol. 9, 1980, pp. 25-28.

[34] G. E. Westlake, P. J. Bunyan, A. D. Martin, P. I. Stanley and L. C. Streed, "Organophosphate Poising Effect of Selected Esterase's of Japanese Quail,” Journal Agriculture of Food Chemistry, Vol. 29, 1981, pp. 272-278.

[35] H. A. Mekkawy, M. G. Ali and A. M. El-Zawahry, "Toxic Effect of Synthetic and Natural Food Dyes on Renal and Hepatic function in Rats," Toxicology Letters, Vol. 95, No. 1, 1998, p. 155. doi:10.1016/S0378-4274(98)80621-8

[36] E. Tareke, P. Rydberg, S. Eriksson and M. Tornavist, "Analysis of Acrylamide a Carcinogen Formed in Heated Food Stuffs," Journal Agriculture of Food Chemistry, Vol. 50, No. 17, 2002, pp. 4998-5006. doi:10.1021/jf020302f

[37] M. E. Awad, M. S. Abdel-Rahaman and S. A. Hassan, “Acrylamide Toxicity in Isolated Rat Hepatocytes," Toxicology in Vitro, Vol. 12, No. 6, 1998, pp. 677-704. doi:10.1016/S0887-2333(98)00051-4

[38] L. Koplorich, "Immunochemical Pattern AST Isoenzymes in Several Rodent and Ehrlich as Cites Cells in Proceeding of the Society for Experimental," Biology and Medicine, Vol. 148, 1975, pp. 410-413.

[39] A. A. Ashour and I. Abdul-Aziz, "Role of Fast Green on the Blood of Rats and the Therapeutic Action of Vitamin C or E. Int,” Journal of Integrative Biology, Vol. 6, No. 1, 2009, pp. 6-11.

[40] M. T. Smith and S. Orreinus, "Drug Metabolism and Drug Toxicity,” R. J. Mitchel and M. G. Horning, Eds., Raven Press, New York, 1984, p. 71.

[41] H. El-Sayyad, M. Abou-Egla, F. I. El-Sayyad, H. ElGhawet, R. L. Gaur, A. Fernand, M. H. G. Raj and A. Ouhtit, "Effect of Fried Potato Chips Supplementation on Mouse Pregnancy and Fetal Development,” Nutrition, Vol. 27, No. 3, 2011, pp. 343-350. doi:10.1016/j.nut.2010.11.005

[42] S. Sharma, R. P. Goyal, G. Chakravarty and A. Sharma, "Toxicity of Tomato Red, a Popular Food Dye Blend on Male Albino Mice,” Experimental and Toxicological Pathology, Vol. 60, No. 1, 2008, pp. 51-57. 